Article

\title{
Co-Composting of Khat-Derived Biochar with Municipal Solid Waste: A Sustainable Practice of Waste Management
}

\author{
Zewdu Abebe Tessfaw ${ }^{1}$, Abebe Beyene ${ }^{1}$, Amsalu Nebiyu ${ }^{2}$, Krzysztof Pikon ${ }^{3}$ \\ and Marcin Landrat ${ }^{3, *}$ \\ 1 Department of Environmental Health Sciences and Technology, Jimma University, P.O. Box 378, Jimma, \\ Ethiopia; zewdu_abebe@dmu.edu.et (Z.A.T.); abebe.beyene@ju.edu.et (A.B.) \\ 2 Department of Horticulture and Plant Sciences, Jimma University, P.O. Box 378, Jimma, Ethiopia; \\ amsalu.nebiyu@ju.edu.et \\ 3 Department of Technologies and Installations for Waste Management, Silesian University of Technology, \\ 44-100 Gliwice, Poland; krzysztof.pikon@polsl.pl \\ * Correspondence: marcin.landrat@polsl.pl; Tel.: +48-32-2371293
}

Received: 30 November 2020; Accepted: 16 December 2020; Published: 21 December 2020

\begin{abstract}
Biochar is a way to improve the performance of the composting process and the quality of compost. This study was aimed to investigate the optimum ratio of khat straw (Catha edulis) biochar and organic municipal solid waste mixtures to improve the quality of the resulting co-composts. Khat-derived biochar during pyrolysis at $350^{\circ} \mathrm{C}$ was added to organic municipal solid waste mix and four co-composting treatments were prepared with the compositions $(\% w / w)$ : control compost (no biochar) and 5\%, 15\%, and 25\% co-composted biochar in three replicates. The total organic carbon, organic matter, total nitrogen, available phosphorus, and potassium values ranged as $16.76-21.45 \%$, $30.77-40.26 \%, 0.97-1.68 \%, 0.58-0.76 \%$, and $12.72-15.29 \%$, respectively. The results confirmed that $5 \%$ and $15 \%$ co-composted khat biochars had significantly reduced $(p<0.05)$ organic matter loss and increased the contents of cation exchange capacity, $\mathrm{pH}$, phosphorous, potassium, calcium, magnesium, and zinc compared to the control compost, while some heavy metals ( $\mathrm{Fe}, \mathrm{Cu}$, and $\mathrm{Mn}$ ) and EC values in co-composted biochars are lower than the control compost. Khat-derived biochar could be added to municipal organic waste mix at $5-15 \%(w / w)$ in order to get better quality of compost, which can be used as biofertilizer.
\end{abstract}

Keywords: biochar; co-composted biochar; compost; municipal solid waste mix

\section{Introduction}

The sustainable management of solid waste has become a major problem of the municipalities in the world in general and developing countries in particular [1,2]. Jimma, South-west Ethiopia as city of a developing country, solid waste collection rate is the lowest among the growing cities of Ethiopia, where only $30 \%$ of the total waste is collected and disposed on landfills [3]. The remaining part of the waste is usually burned or disposed in open space. According to Getahun et al. [3], the total waste generated daily in Jimma city was ca. $88,000 \mathrm{~kg}$, and the average per capita generation rate was $0.55 \pm 0.17 \mathrm{~kg} / \mathrm{capita} /$ day. In addition, according to [3], biodegradable organic waste constitutes $88.6 \%$ by weight. Thus, the proper management of organic solid waste is crucial for the successful disposal of municipal solid waste.

Composting has been considered as the most sustainable way to recycle organic wastes for the ever-increasing volume of municipal solid wastes being generated [4-7]. Composting is a method for converting organic wastes into compost, and it has advantages over other disposal strategies because 
it reduces the volume of waste by $40-50 \%$ and provides nutrient-rich biofertilizer. In recent years, compost and other organic amendments has received increasing attention over chemical fertilizers in both providing enough nutrients and improving the soil environment, which leads to increased yields of crops [8].

However, composting had been associated with greenhouse gas emission $\left(\mathrm{CO}_{2}, \mathrm{~N}_{2} \mathrm{O}\right.$, and $\left.\mathrm{CH}_{4}\right)$, leachate generation, but this emission is not as equally harmful for climate as coal combustion $[9,10]$. More recently, studies have showed that biochar is a way to improve the performance of the composting process and the quality of compost [11,12]. Experimental evidences of biochar impact on composting especially in tropical systems are limited to a few studies to date. However, the available literature reported that biochar addition during composting provides positive effects such as adjusting the $\mathrm{C}: \mathrm{N}$-ratio and serving as a bulking agent [13], reducing ammonia $\left(\mathrm{NH}_{3}\right)$ and greenhouse gas (GHG) emissions [14], increasing heavy metal stabilization and rapid organic matter degradation [15], enhancing microbial activities [16], and upgrading compost quality by increasing the available nutrient content $[17,18]$. Biochar can either be mixed with composting feedstocks during the composting process, i.e., "co-composted," or added directly to stored matured compost [14].

Biochar is charcoal produced from biomass by pyrolysis in a low-oxygen environment for use as a soil amendment or carbon sequestration [19]. Although some recent studies have indicated that biochar alone application to soil can improve soil fertility and plant growth $[20,21]$, the combined use of biochar with other, nonpyrolyzed organic amendments (i.e., compost, manure, plant litter, etc.) has been proposed $[11,22,23]$. The properties of biochar depend on the type of the feedstock and pyrolysis conditions [24]. The selection of a specific type of feedstock is to a great extent determined by the availability of this material in the area where the biochar is likely to be produced. Large quantities of khat straw are produced during chewing khat leaves has left large quantity of khat straw as major part of municipal solid waste that is dumped in large quantity in Jimma city. With its low moisture content and local availability in the municipal waste, khat straw could be an important feedstock for biochar production. However, the ability of khat straw-derived biochar to affect compost quality might vary depending on its characteristics. It is, therefore, essential to investigate the properties before wide application of khat straw-derived biochar.

On the other hand, a biochar impact on composting has been ranged in a wide proportion of biochar, from $2 \%$ to $50 \%(w / w)$, which is yet not fully understood $[11,13,25,26]$. Knowledge about an optimum proportion of biochar addition would be necessary to maximize the potential benefit of biochar and compost on the future use [17]. It is, therefore, crucial to investigate the optimum ratio of khat straw (Catha edulis) biochar and organic fraction of municipal solid wastes to improve the quality of the resulting composts.

\section{Materials and Methods}

\subsection{Municipal Solid Waste Collection}

All personnel collecting, handling, and transporting of the wastes were performed using proper procedures according to the waste established classes. The municipal solid organic wastes used for the pyrolysis and composting experiments were khat (Catha edulis) straws, dry grass and leaves, coffee ground, and vegetable wastes (cabbage, avocado and banana peel). These wastes were obtained by a door-to door collection and source segregation from households, hotels, roads, markets, and shops in Jimma city for a week in sealed bags until ready for biochar and compost production. These waste ingredients were selected on the basis of their availability in the municipal solid wastes. Biochar was used as bulk agent for composting process. Sun-dried grass clippings and fallen leave wastes were used as a source of carbon and coffee grounds and vegetable wastes (cabbage, avocado, and banana peel) were used as sources of nitrogen for composting. Wastes such as onion and garlic, which repel earthworm, and anything containing meat, fat, oil, and dairy products, which bring bad smell, were avoided. 


\subsection{Biochar Production}

The khat (Catha edulis) straw waste was used for biochar production. Laboratory experiments were conducted with a laboratory-scale pyrolysis reactor at Jimma University agricultural college. The biomass samples were washed and dried. Some sample of khat straw was powdered and subjected to initial compositional analysis and the remaining was used for pyrolysis and composting experiments. Khat straw waste was pyrolyzed at a temperature of $350{ }^{\circ} \mathrm{C}$ at a heating rate $5^{\circ} \mathrm{C} / \mathrm{min}$ for $4 \mathrm{~h}$ (Figure 1). Approximately, $7.0 \mathrm{~kg}$ of khat straw wastes was used in the batch slow pyrolysis experiments. After cooling and opening the kiln, the biochar was removed and weighted. About $2.04 \mathrm{~kg}$ (29.4\%) of char was produced from each of the batch experiment. Ref. [27] in their studies have showed that feedstocks with higher content of lignin have higher biochar yield, while biomass with higher content of cellulose and hemicellulose resulted in production of more volatile compounds. The biochar yield for typical slow pyrolysis process is about 35\% [28]. So, from our finding we observed that khat straw has a good content of lignin since it's biochar yield is about $29.4 \%$.

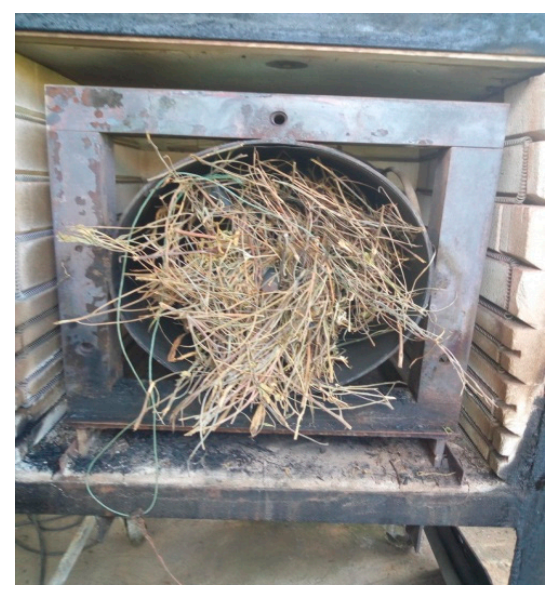

(a)

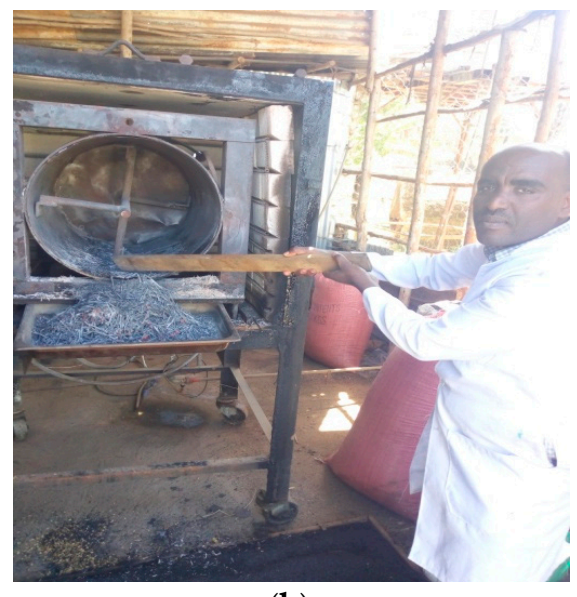

(b)

Figure 1. Preparation of biochar during slow pyrolysis of khat straw: (a) khat straw into the reactor and (b) biochar collected from the reactor.

\subsection{Compost and Composted-Biochar Production}

The production of compost with and without biochar was carried out in three replicates with a laboratory-scale chamber compost bioreactor made of clay with a total working capacity of $1 \mathrm{~m}^{3}$ in October-December 2018 (about 88 days) at Agricultural College Research Center, Jimma University, Ethiopia. On the basis of their availability and to optimize the $\mathrm{C}: \mathrm{N}$ ratio, the organic municipal waste feedstocks were mixed with a proportion of $40 \mathrm{~kg}$ of vegetables (banana $(15 \mathrm{~kg})+$ cabbage $(20 \mathrm{~kg})$ + avocado $(5 \mathrm{~kg})), 100 \mathrm{~kg}$ of sun dried fallen leave and grass, and $40 \mathrm{~kg}$ of coffee ground wastes. Following the initial organic municipal waste mixtures, four co-composting treatments were prepared with biochar in three replicates (Table 1). C:N ratio is among the parameters, which mainly affects the quality of the end compost. Data reported by [18] showed that $2-50 \%(w / w)$ biochar application rates led to different effects on the quality of compost and composting process.

Table 1. The types of compost treatments and proportions of organic municipal waste feedstocks mixture and biochar.

\begin{tabular}{cccc}
\hline Sr. No. & Types of Compost Treatments & Organic Waste Mix $(\% w / w)$ & Biochar $(\% w / w)$ \\
\hline 1 & Control compost mix (no biochar) & 100 & 0 \\
2 & $5 \%$ co-composted biochar & 95 & 5 \\
3 & $15 \%$ co-composted biochar & 85 & 15 \\
4 & $25 \%$ co-composted biochar & 75 & 25 \\
\hline
\end{tabular}


The experiment was carried out in the laboratory with an average room temperature of $23 \pm 2.0^{\circ} \mathrm{C}$ and relative humidity as $70 \%$. The co-composting substrates were turned every week until the end of the experiment and four types composts (Figure 2) were produced.

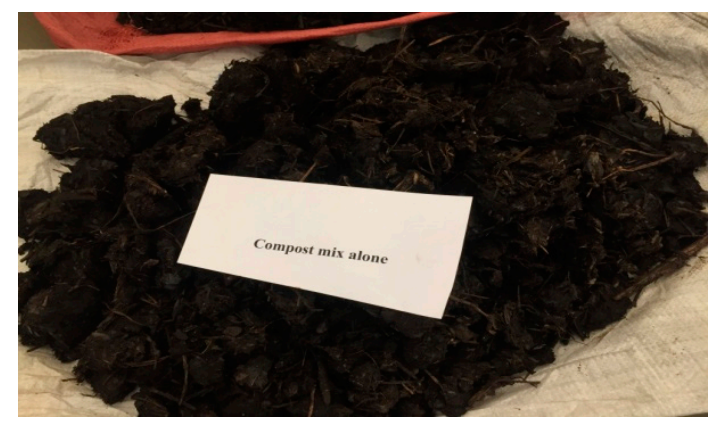

(a)

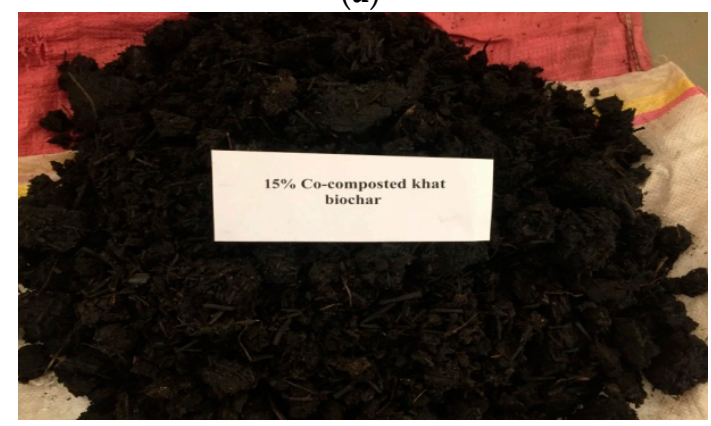

(c)

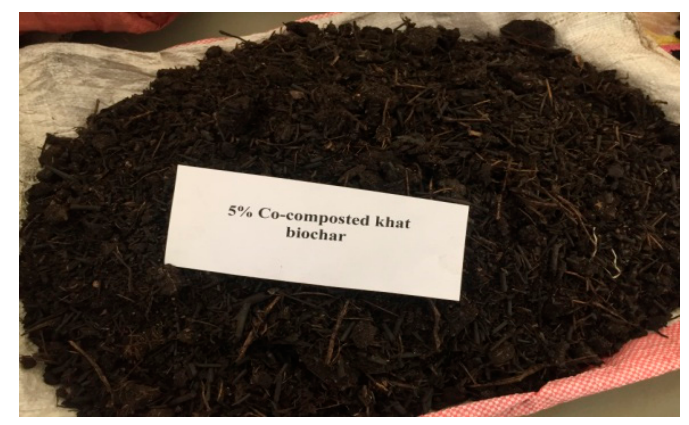

(b)

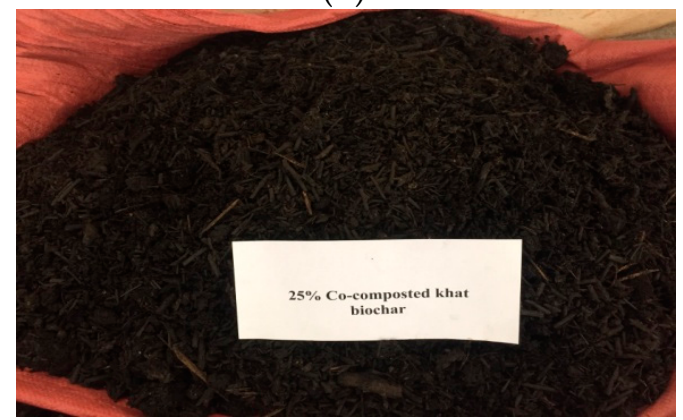

(d)

Figure 2. The co-composted khat biochar produced by mixing organic fraction of municipal waste with (a) 100\% organic waste mix (no biochar), (b) 5\% of khat biochar, (c) 15\% khat biochar, and (d) $25 \%$ khat biochar.

\subsection{Physicochemical Analysis}

The moisture contents of khat biochar, organic waste mix, and composts were determined by placing $5.0 \mathrm{~g}$ of each sample in a dry Petri dish in a hot air oven for $24 \mathrm{~h}$ at $105^{\circ} \mathrm{C}$, after the moisture was removed, the organic matter was determined from mass loss by furnace ignition at $550{ }^{\circ} \mathrm{C}$ for about $8 \mathrm{~h}$.

Total nitrogen was determined by Kjeldahl method and organic carbon (OC) was determined by the Walkley and Black titration method, which is based on the oxidation of biomass by potassium dichromate $\left(\mathrm{K}_{2} \mathrm{Cr}_{2} \mathrm{O}_{7}\right)$ and sulfuric acid mixture followed by back titration of the excessive dichromate by ferrous ammonium sulfate [29]. The $\mathrm{pH}$ and electrical conductivity (EC, dS/m) were determined in the supernatant solution of 1:5 compost or feedstock/water ratio (w/v) [30] using a $\mathrm{pH}$ meter and conductivity bridge/meter [31], respectively. Potassium (K), calcium (Ca), and magnesium $(\mathrm{Mg})$ were determined from 2 gm of dry compost sample extracted with $10 \mathrm{~mL}$ of $1 \mathrm{~N}$ ammonium acetate kept for overnight and filtered using Whatman paper number 42 and final volume was diluted up to $50 \mathrm{~mL}$ deionized water. Ammonium acetate extract of the compost samples was determined by atomic absorption spectroscopy (AAS) [32] and cation exchange capacity (CEC) by the ammonium acetate method [33]. Heavy metals ( $\mathrm{Fe}, \mathrm{Mn}, \mathrm{Cu}, \mathrm{Zn}, \mathrm{Cd}, \mathrm{Cr}$, and $\mathrm{Pb}$ ) were determined by atomic absorption spectroscopy (model NOVA 400P AAS) after digestion of the composts and biochar with a blend of $\mathrm{HNO}_{3}$ and $\mathrm{HClO}_{4}$ [31]. Available phosphorus was determined by leaching the sample with $0.002 \mathrm{~N}$ $\mathrm{H}_{2} \mathrm{SO}_{4}$ ( 1 soil: $200 \mathrm{H}_{2} \mathrm{SO}_{4}$ suspension $w / v$ ) and shaken for at least 30 min and filtered through Whatman filter paper No. 42 to get a clear solution. The amount of phosphorus in the extract was estimated by chlorostannous reduced phosphomolybdate blue color method using spectrophotometer at the wavelength of $690 \mathrm{~nm}$ [31]. 


\subsection{Statically Analysis}

Statistical analysis was carried out using statistical package SPSS (IBM SPSS Statistic 24). One-way analysis of variance (ANOVA) was applied to evaluate the significant differences among the mean values of treatments; F values $(p=0.05)$ were tested. Means were tested by Tukey's HDS test at a 5\% level of confidence [34]. All samples were analyzed in triplicates $(n=3)$. The results were presented as mean values \pm standard deviation, $\mathrm{n}=3$.

\section{Results and Discussion}

\subsection{The Physicochemical Properties of Khat Straw Biochar}

The physicochemical properties of khat straw biochar are presented in Table 2. It has low moisture content $(9.7 \%)$, which initiates khat straw biochar to use as bulking agent during composting. This value is lower than the finding by [12] for biochar produced from bamboo tree. It has an electrical conductivity (EC) value of $1.6 \mathrm{dS} / \mathrm{m}$, which is much less than the maximum limit $(4.0 \mathrm{dS} / \mathrm{m})$ of Greek's standard for agricultural uses [35]. The electrical conductivity is the measure of water-soluble salts. The EC value of this biochar is good because it is low. Khat biochar has also weak alkaline $\mathrm{pH}$ (8.9) value, which is important to neutralize the acidic organic waste mix during composting or to amend acidic soil. This $\mathrm{pH}$ value was less than the findings by [14] for biochar prepared from holm oak, which was pyrolyzed at $650^{\circ} \mathrm{C}$, but greater than the finding by [13] for biochar prepared from Eucalyptus grandis pyrolyzed at $300-450^{\circ} \mathrm{C}$. The results also showed that khat straw biochar has high organic matter $(88.4 \%)$ as well as major nutrients such as total nitrogen $(1.50 \%)$, phosphorous $(0.40 \%)$, potassium $(0.26 \%)$, calcium $(6.4 \mathrm{~g} / \mathrm{kg})$, and magnesium $(2.3 \mathrm{~g} / \mathrm{kg})$ contents with low levels of trace metals. These results were within the range of the values found by [36], in which biochars were pyrolyzed from six feedstocks types, the nutrient contents (\%) ranged as total organic carbon from 34.96 to $48.93, \mathrm{~N}$ from 0.56 to 2.00 , $\mathrm{P}$ from 0.49 to 2.49 , and $\mathrm{K}$ from 1.41 to 7.49 . Wu et al. [24] also reported that the rice straw-derived biochars produced at $400{ }^{\circ} \mathrm{C}$ had high $\mathrm{pH}$ (10.1) and cation exchange capacity $(57.2 \mathrm{cmol} / \mathrm{kg})$ and high levels of available phosphorus $(830 \mathrm{mg} / \mathrm{kg})$ and extractable cations, which were higher than the values from our observation. In the findings by [14], some of the results, $\mathrm{pH}(10.1), \mathrm{C}(74.2 \%), \mathrm{P}(2.4 \mathrm{~g} / \mathrm{kg})$, and $\mathrm{Ca}(69.8 \mathrm{~g} / \mathrm{kg})$, were greater and others, EC (0.67), $\mathrm{OM}(77.8 \%)$, and $\mathrm{N}(0.5 \%)$, were less than our results. The variation in the physiochemical properties of biochar vastly depend on pyrolysis condition and the feedstock used [37].

Table 2. The physicochemical properties of khat straw biochar pyrolyzed at $350{ }^{\circ} \mathrm{C}$. Results expressed as mean values $\pm \mathrm{SD}, \mathrm{n}=3$.

\begin{tabular}{cccccccccccccc}
\hline MC & EC & pH & OM & OC & N & P & K & Ca & Mg & Fe & Mn & $\mathbf{C u}$ & $\mathbf{Z n}$ \\
\hline$\%$ & $\mathbf{d S} / \mathbf{m}$ & $\mathbf{( H _ { 2 } \mathbf { O } )}$ & $\%$ & $\%$ & $\%$ & $\%$ & $\%$ & g/kg & & mg/kg & \\
\hline $9.7 \pm$ & $1.6 \pm$ & $8.9 \pm$ & $88.4 \pm$ & $47.7 \pm$ & $1.5 \pm$ & $0.4 \pm$ & $0.26 \pm$ & $6.4 \pm$ & $2.3 \pm$ & $1.1 \pm$ & $0.3 \pm$ & $0.1 \pm$ & $0.2 \pm$ \\
0.23 & 0.02 & 0.01 & 0.67 & 0.36 & 0.03 & 0.09 & 0.01 & 0.02 & 0.01 & 0.01 & 0.00 & 0.00 & 0.00 \\
\hline
\end{tabular}

Thus, the physicochemical properties of khat straw biochar indicate that it is could be used as bulking agent for composting or to amendment degraded soil either alone or in synergy with compost or inorganic fertilizer.

\subsection{The Chemical and Moisture Contents of Organic Municipal Waste Mix and Compost with and without Khat Biochar Amendments}

The chemical properties of initial municipal organic waste mix and compost with and without khat-derived biochar are presented in Table 3. The electrical conductivity (EC) values ranged from 0.42 to $0.75 \mathrm{dS} / \mathrm{m}$ for the different compost types. The EC value of initial organic waste mix $(2.22 \mathrm{dS} / \mathrm{m})$ was significantly reduced during composting for both with and without khat-derived biochar $(p<0.05)$ (Table 3). During the composting process, the clay reactor chambers were closed and there was no 
loss of leachates, but gases mainly ammonia could be lost, which decreased the EC values of the resulting compost piles. There were contradicted ideas in literature about EC values during composting. Zhang et al. [38] observed an increase in EC, while Wu et al. [17] reported a decrease in EC values during composting. The decrease in $\mathrm{EC}$ of the initial organic waste mix during composting was because of the soluble forms of heavy metals, which were accumulated and immobilized, or precipitated mineral salts in the weak alkaline compost mixture [39]. Previous studies showed that heavy metals are converted to insoluble forms in neutral or alkaline media. Electrical conductivity (EC) is one of simple indicators of suitability of a waste for agricultural uses, because it reflects the salinity of the resulting organic amendments and low salinity is suitable for agriculture. The maximum limit of EC value of compost for agricultural use in Greek standards is $4.0 \mathrm{dS} / \mathrm{m}$ [35]. Since, all the under studied composts' EC values were less than the maximum limit, they are suitable for agricultural applications in terms of EC values.

Table 3. The physicochemical properties of initial municipal organic solid waste mix and the four different types of co-composted khat-derived biochars. Results are expressed as mean values $\pm \mathrm{SD}$, $\mathrm{n}=3$.

\begin{tabular}{ccccccc}
\hline & & \multicolumn{4}{c}{ Treatments } \\
\hline Parameters & Units & $\begin{array}{c}\text { Initial } \\
\text { Organic } \\
\text { Waste Mix }\end{array}$ & $\begin{array}{c}\text { Control } \\
\text { Compost }\end{array}$ & $\begin{array}{c}\mathbf{5} \% \\
\text { Co-Composted } \\
\text { Biochar }\end{array}$ & $\begin{array}{c}\text { 15\% } \\
\text { Co-Composted } \\
\text { Biochar }\end{array}$ & $\begin{array}{c}\text { 25\% } \\
\text { Co-Composted } \\
\text { Biochar }\end{array}$ \\
\hline $\mathrm{EC}$ & $\mathrm{dS} / \mathrm{m}$ & $2.22 \pm 0.0 \mathrm{a}$ & $0.75 \pm 0.0 \mathrm{~b}$ & $0.51 \pm 0.0 \mathrm{c}$ & $0.63 \pm 0.0 \mathrm{~d}$ & $0.42 \pm 0.0 \mathrm{e}$ \\
\hline $\mathrm{pH}\left(\mathrm{H}_{2} \mathrm{O}\right)$ & & $6.12 \pm 0.0 \mathrm{a}$ & $8.24 \pm 0.3 \mathrm{~b}$ & $8.29 \pm 0.3 \mathrm{~b}$ & $8.52 \pm 0.4 \mathrm{~b}$ & $8.61 \pm 0.2 \mathrm{~b}$ \\
\hline Moisture content & $\%$ & $63.09 \pm 1.6 \mathrm{a}$ & $53.8 \pm 1.2 \mathrm{~b}$ & $47.57 \pm 0.9 \mathrm{c}$ & $46.85 \pm 0.6 \mathrm{c}$ & $44.54 \pm 0.8 \mathrm{c}$ \\
\hline Organic matter & $\%$ & $58.24 \pm 3.9 \mathrm{a}$ & $33.32 \pm 0.4 \mathrm{~b}$ & $40.26 \pm 0.8 \mathrm{c}$ & $37.09 \pm 0.9 \mathrm{c}$ & $30.77 \pm 1.3 \mathrm{~b}$ \\
\hline Total organic carbon & $\%$ & $31.45 \pm 2.1 \mathrm{a}$ & $18.00 \pm 0.5 \mathrm{bde}$ & $21.45 \pm 0.8 \mathrm{~cd}$ & $19.38 \pm 0.3 \mathrm{bcd}$ & $16.76 \pm 1.1 \mathrm{be}$ \\
\hline CEC & $\mathrm{cmol}(+) / \mathrm{kg}$ & $73.41 \pm 0.5 \mathrm{a}$ & $105.4 \pm 0.7 \mathrm{~b}$ & $177.95 \pm 1.1 \mathrm{c}$ & $121.61 \pm 0.7 \mathrm{~d}$ & $112.06 \pm 2.7 \mathrm{e}$ \\
\hline C:N ratio & $\mathrm{g} / \mathrm{g}$ & $17.42 \pm 1.8 \mathrm{a}$ & $11.26 \pm 0.6 \mathrm{~b}$ & $14.97 \pm 0.8 \mathrm{c}$ & $16.07 \pm 1.7 \mathrm{ac}$ & $17.33 \pm 0.8 \mathrm{a}$ \\
\hline
\end{tabular}

Tukey HSD ( $p<0.05 ;$ means within a row followed by different letters are significantly different).

The $\mathrm{pH}\left(\mathrm{H}_{2} \mathrm{O}\right)$ values of the different composts are in the range of weak alkaline media (8.24-8.61) and acidic (6.12) for initial organic waste mixture (Table 3). The findings of this study showed that the variation in $\mathrm{pH}$ was significant $(p<0.05)$ between the initial organic waste mix and all composts, but the same between the control compost and khat-derived biochar amended composts (Table 3). The result was higher than the finding by [40]. Our results showed that during composting, the $\mathrm{pH}$ of the initial organic waste mixture was increased for both with and without khat-derived biochar. This is because the khat-derived biochar had higher contents of basic cations $(\mathrm{K}, \mathrm{Ca}$, and $\mathrm{Mg})$, and these cations are leached to the compost piles from the biodegradation of organic waste and biochar mixture during composting. There were contradictory ideas in recent literatures on the $\mathrm{pH}$ value during composting. According to the observation by [38], the addition of wheat straw biochar from $0 \%$ to $15 \%(w / w)$ reduced the $\mathrm{pH}$ during composting. Vandecasteele et al. [14] observed that biochar addition slightly increased the initial $\mathrm{pH}$ of the compost mixture. Experimental evidences showed that a biochar amendment increases the $\mathrm{pH}$ of a soil. The $\mathrm{pH}$ value increased with increasing the rate of khat-derived biochar. There was slight increase in the $\mathrm{pH}$ value with increasing rate of khat-derived biochar. The trend is similar with the report by [13], in which the application of alkaline biochar as a bulking agent at highest rate in poultry manure compost obtained the highest $\mathrm{pH}$ for the matured compost. The $\mathrm{pH}$ values of all composts were within the optimum range (6-8.5). The results were in agreement with the investigation by [40] for compost prepared from organic fraction of municipal solid waste in which the $\mathrm{pH}$ ranged from 6 to 8.5 .

The $\mathrm{pH}$ values of the under investigation composts showed that they are suitable for soil application especially for acidic soil. Compost could correct the $\mathrm{pH}$ of the soil to the optimum, and it has buffering effect. The $\mathrm{pH}$ is a chemical parameter, which affects the amount of nutrients available in the soil, the solubility of heavy metals, and the metabolic activity of the important microorganisms 
in the soil. The optimum soil $\mathrm{pH}$ suitable for crop growth ranges from 6 to 8 . In this $\mathrm{pH}$ range, essential soil nutrients are available for plants in the soil solution, while toxic heavy metals converts to insoluble forms.

The cation exchange capacity (CEC) values for the under studied composts ranges from 73.41 to $177.95 \mathrm{cmol}(+) / \mathrm{kg}$ (Table 3). CEC is one of the important chemical parameters, which indicate the quality of matured compost. According to literature, matured and better quality compost has high CEC value [41]. In this study, we observed that there was significant variation $(p<0.05)$ (Table 3$)$ between CEC values among the investigated composts, while $5 \%$ khat-derived biochar amended compost had the highest value of CEC $(177.95 \mathrm{cmol}(+) / \mathrm{kg})$ and control compost (without khat-derived biochar) had the lowest CEC value $(73.41 \mathrm{cmol}(+) / \mathrm{kg})$. This showed that all the composts with khat-derived biochar were more matured than the control compost. The high value of CEC in biochar amended composts is because of the high contents of basic cations such as $\mathrm{K}, \mathrm{Ca}$, and $\mathrm{Mg}$ in the khat-derived biochar (Table 2). CEC is also correlated with the degree of degradation of biomass during composting, so that the rate of the decomposition was higher in khat-derived biochar amended compost than the control.

The average moisture content during the composting experiment was $63.09 \%$. According the findings by [42], the suitable initial moisture content for the efficient composting of poultry manure mixed with wheat straw ranged from $65 \%$ to $80 \%$. The finding by [43] suggested that pile moisture was maintained between $53 \%$ and $60 \%$ during the composting period. At the end of composting experiment, the different composts' moisture content ranged from $44.54 \%$ to $50.57 \%$ (Table 3). According to literatures, the optimum moisture contents value of the final compost ranged from $35 \%$ to $45 \%$ [44]. The moisture content greatly influences the changes in physical and chemical properties of waste material in course of degradation of organic matter because it affects the microbial activities and aeration. The 5\% khat-derived biochar amended compost caused lower loss of moisture from the compost piles, and the highest loss of moisture was for $25 \%$ khat-derived biochar amended compost. Studies have found the enhanced moisture storage capacity in biochar amended soils even if no direct evidence supported the claim that biochar addition can increase the moisture storage capacity of compost piles [18].

Khat-derived biochar increased the organic matter and the total carbon of composting (Table 3). The organic matter and total organic carbon contents of the different composts ranged from $30.77 \%$ to $40.27 \%$ and $16.76 \%$ to $21.45 \%$, respectively. The organic matter content of initial organic municipal feedstocks mix was $58.22 \%$. The loss of organic matter from biomass during composting was mainly as $\mathrm{CO}_{2}, \mathrm{CH}_{4}, \mathrm{NO}_{\mathrm{x}}, \mathrm{N}_{2} \mathrm{O}, \mathrm{NH}_{3}, \mathrm{SO}_{\mathrm{x}}$, and $\mathrm{H}_{2} \mathrm{~S}$. The loss in organic matter content was in the order of $47 \%$, $43 \%, 37 \%$, and $30 \%$ for $25 \%$ khat-derived biochar amended compost, control compost, $15 \%$ khat-derived biochar amended composts, and 5\% khat-derived biochar amended composts, respectively. The organic matter loss was greater in compost without khat-derived biochar than $5 \%$ and $15 \%$ khat-derived biochar amended composts but, lower than $25 \%$ khat-derived biochar amended compost. This is because, biochar is characterized by stable carbon, and the composting mixture prepared with biochar underwent an organic matter degradation with lower loss. However, the loss of organic matter during decomposition was optimum for the khat-derived biochar rates from $5 \%$ to $15 \%(w / w)$. The result was agreed with the investigation by [13] in which the organic matter loss for composting of biochar with poultry manure was 30\%. According to [45], the degradation of organic matter was between $19 \%$ and 39\% within 133 days. The total organic carbon content was also changed among the compost treatments in similar fashion with the observation for organic matter. The organic matter was lost during composting as $\mathrm{CO}_{2}, \mathrm{CH}_{4}$, and $\mathrm{CO}$, and the initial total organic carbon was reduced in the compost piles. However, the rate of loss of organic carbon was highest for the compost without biochar amendment than with biochar. This is because the biodegradation process during composting derives carbon to the compost piles from the khat-derived biochar and also mixing biochar with compost can accelerate this process and reduce nutrient losses [17]. According to [26], the addition of biochar in combination with barley straw to hen manure reduced total GHG emissions (as $\mathrm{CO}_{2}$ equivalents) by $27-32 \%$ compared with barley straw addition alone. 
The C:N ratio of the composts and the organic fraction of municipal solid wastes under studied are given in Table 3. The C:N ratio ranged from 11.26:1 to 17.33:1 for the different co-compost khat-derived biochar types. Jindo et al. [46] found that the C:N ratio of biochar amended poultry manure compost was about 21.7, which is greater than our observations. Khan et al. [43] also found that the C:N ratio of final compost containing chicken manure and sawdust mixed with biochar at rates of $5 \%$ and $10 \%$, respectively, ranged from 31.5:1 to 35.7:1, which was much higher than our observations. The findings of this study are in agreement with the results by [47], which support that the application of biochar increased the C:N ratio. The C:N ratio is a traditional parameter, which has been used to evaluate the compost maturity and stability [48]. Previous studies showed that the optimum C:N ratio of the final compost should be reduced to between 10:1 and 15:1 as an indicator of better quality of compost [49]. Microorganisms require $\mathrm{C}, \mathrm{N}$, phosphorus $(\mathrm{P})$, and potassium $(\mathrm{K})$ as the primary nutrients. The $\mathrm{C}: \mathrm{N}$ ratio is particular importance, which influences the composting process, microbial community, and also the composition and quality of the end product. During the composting experiment, we used dry leaves and grass clippings as sources of carbon and cabbage, avocado, banana and coffee ground wastes as nitrogen sources. The initial organic waste mix C:N was 17.42:1, which was satisfactory. The initial C:N ratio between 15 and 30 will consistently bring about good composting results [49].

The concentrations of total nitrogen $(\mathrm{N})$ for the municipal organic waste mixture and the different composts are showed in Table 4 . The total $\mathrm{N}$ content (\%) ranged from 0.97 to 1.68 for the composts and 1.81 for the initial organic municipal waste mixture. The result showed that the optimum khat-derived biochar amended compost $(5 \% w / w)$ had the highest contents of $\mathrm{N}$ than the control compost. The nitrogen loss was about $8.2 \%$ for $5 \%$ khat-derived biochar amended compost and $24.3 \%$ for compost without biochar. The results indicated that during composting process, the nitrogen loss was $16.1 \%$ higher for compost without biochar than with optimum khat-derived biochar rate $(5 \%)$ amended compost. The results also showed that above the optimum rate of khat-derived biochar, the loss in $\mathrm{N}$ was the highest during composting. Lopez-Cano et al. [50] also found that the incorporation of a small amount of biochar (4\%) into composting of olive mill waste reduced the total nitrogen loss by $15 \%$. About $3 \%$ of the initial $\mathrm{N}$ amount was lost in municipal solid waste compost with $10 \%(v / v)$ biochar addition compared with $22 \%$ of initial $\mathrm{N}$ amount loss in the control [14]. According to [15], the loss of nitrogen during composting is primarily regulated by the initial C/N ratio with the optimal values from 20:1 to 30:1. The findings of different studies showed that the rate of loss of nitrogen during composting of different organic waste varies and can constitute even more than $70 \%$ [15]. During composting $\mathrm{N}$ is mainly lost as ammonia $\left(\mathrm{NH}_{3}\right)$ [51]. From the study, we observed high content of nitrogen in the studied composts. This is because the volatilization of $\mathrm{NH}_{3}$ is reduced at lower environmental temperature in which the composting experiment was performed at lower room temperature $\left(23^{\circ} \mathrm{C}\right)$. Vandecasteele et al. [14] also indicated that the higher ammonium adsorption was found in the case of the feedstock mixture amended with biochar. Another mechanism of biochar during composting is elevating the $\mathrm{C}: \mathrm{N}$ ratio that causes the threat of nitrogen immobilization [52].

Table 4. The concentrations of macronutrients in the initial organic waste mix and different types of co-composted khat-derived biochar. Results are expressed as mean values $\pm S D, n=3$.

\begin{tabular}{ccccccc}
\hline & \multicolumn{5}{c}{ Treatments } \\
\hline Parameters & Units & $\begin{array}{c}\text { Initial } \\
\text { Organic } \\
\text { Waste Mix }\end{array}$ & $\begin{array}{c}\text { Control } \\
\text { Compost }\end{array}$ & $\begin{array}{c}\mathbf{5 \%} \\
\text { Co-Composted } \\
\text { Biochar }\end{array}$ & $\begin{array}{c}\text { Co-Composted } \\
\text { Biochar }\end{array}$ & $\begin{array}{c}\text { 15\% } \% \\
\text { Co-Composted } \\
\text { Biochar }\end{array}$ \\
\hline $\mathrm{N}$ & $\%$ & $1.81 \pm 0.03 \mathrm{a}$ & $1.37 \pm 0.03 \mathrm{~b}$ & $1.68 \pm 0.10 \mathrm{c}$ & $1.54 \pm 0.02 \mathrm{~d}$ & $0.97 \pm 0.05 \mathrm{e}$ \\
$\mathrm{P}$ & $\%$ & $0.26 \pm 0.09 \mathrm{a}$ & $0.58 \pm 0.04 \mathrm{~b}$ & $0.76 \pm 0.10 \mathrm{c}$ & $0.64 \pm 0.06 \mathrm{~d}$ & $0.62 \pm 20 \mathrm{e}$ \\
$\mathrm{K}$ & $\%$ & $7.49 \pm 0.15 \mathrm{a}$ & $12.7 \pm 0.15 \mathrm{~b}$ & $13.6 \pm 0.02 \mathrm{c}$ & $14.7 \pm 0.11 \mathrm{~d}$ & $15.3 \pm 0.20 \mathrm{e}$ \\
$\mathrm{Ca}$ & $\mathrm{g} / \mathrm{kg}$ & $8.91 \pm 0.05 \mathrm{a}$ & $9.65 \pm 0.03 \mathrm{~b}$ & $9.91 \pm 0.08 \mathrm{c}$ & $9.56 \pm 0.05 \mathrm{~d}$ & $9.42 \pm 0.02 \mathrm{e}$ \\
$\mathrm{Mg}$ & $\mathrm{g} / \mathrm{kg}$ & $2.54 \pm 0.02 \mathrm{a}$ & $2.77 \pm 0.15 \mathrm{~b}$ & $2.86 \pm 0.4 \mathrm{c}$ & $2.99 \pm 0.50 \mathrm{~d}$ & $3.21 \pm 0.15 \mathrm{e}$ \\
\hline \multicolumn{2}{c}{ Tukey HSD $(p<0.05 ;$ means within a row followed by different letters are significantly different $)}$.
\end{tabular}


The concentrations of available phosphorous $(\mathrm{P})$ and potassium $(\mathrm{K})$ among the composts with and without khat-derived biochar amendments and the initial organic waste mixtures are illustrated in Table 4 . The values of available P ranged from $0.58 \%$ to $0.76 \%$ for the under studied composts and $0.26 \%$ for the initial organic municipal feedstocks mixture. From the study, we observed that the initial available phosphorous content was increased significantly $(p<0.05)$ for all treatments during composting. The improvement of phosphate content in compost with biochar was mostly due to high phosphorus $(\mathrm{P})$ reserves in the biochar added [27] and mineralization and microbial utilization of organic P compounds [14]. As showed in Table 4, khat-derived biochar also increased the available $\mathrm{P}$ during composting, and the maximum $\mathrm{P}$ was recorded for $5 \%$ khat-derived biochar amended compost. The optimum khat-derived biochar rate (5\%) increased the available P by $69.2 \%$ more than the control compost (compost without khat-derived biochar). All the composts had enough contents of $\mathrm{P}$ and proved to be important sources of available $\mathrm{P}$, and the contents were above the requirements (10-15 mg/kg P) for most crops range [53]. Kidder et al. [54] suggested that the amount above $57 \mathrm{mg} / \mathrm{kg}$ of $\mathrm{P}$ is risky, and it causes pollution of surface water.

The concentration of K (\%) were 12.72, 13.61, 14.70, and 15.29 for control and $5 \%, 15 \%$, and $25 \%$ khat-derived biochar amended composts, respectively. The concentration of $\mathrm{K}$ for the initial organic waste mix was $7.49 \%$. As showed in Table 4 , the concentrations of $\mathrm{K}$ increased significantly $(p<0.05)$ in all types of composts relative to the initial organic waste mixture. Addition of khat straw-derived biochar increased the concentration of K compared to the control (no biochar). Literature showed that the quantitative changes of all nutrient contents in the end composting product depends on the quality of the feedstocks and input materials. So, the improvement in $\mathrm{K}$ concentration is a result of additional $\mathrm{K}$ from the khat-derived biochar, which has high content of available K (Table 2). Many of potassium compounds are water soluble, and during composting, the biodegradation of compost piles leaches soluble $\mathrm{K}$ to the porous of khat-derived biochar. Both composts with and without khat-derived biochar are considered to be suitable for agricultural application, which have enough contents of $\mathrm{K}$, and are above the requirements of low $\mathrm{K}$ soil (20-35 $\mathrm{mg} / \mathrm{kg}$ ) for most crops range [53].

The contents of calcium (Ca) and magnesium $(\mathrm{Mg})$ for the different composts ranged from 9.42 to 9.91 and 2.77 to $3.21 \mathrm{~g} / \mathrm{kg}$, respectively, and the values in the initial organic waste mix were 8.91 and $2.54 \mathrm{~g} / \mathrm{kg}$, respectively (Table 4). The results showed that the concentration of Ca and Mg was increased significantly $(p<0.05)$ in khat-derived biochar amended composts than the initial organic waste mix and control. This increase is a result of the adsorption of the basic cations on the organic negative charges $\left(\mathrm{COO}^{-}\right)$of biochar. This result agreed with the findings by [54], in which biochar increased the availability of exchangeable base cations $\left(\mathrm{Ca}^{+2}, \mathrm{Mg}^{+2}\right.$, and $\left.\mathrm{K}^{+}\right)$than without biochar. Meller et al. [55] found that the contents of $\mathrm{Ca}$ and $\mathrm{Mg}$ in municipal solid waste compost were 2.94 and $71.26 \mathrm{~g} / \mathrm{kg}$, respectively. Thus, the concentration of $\mathrm{Ca}$ by far less than and concentration of $\mathrm{Mg}$ was similar with this finding.

$\mathrm{Ca}$ and $\mathrm{Mg}$ are essential macronutrients of plants next to $\mathrm{N}, \mathrm{P}$, and $\mathrm{K}$. These nutrients may be removed from soil by different mechanism such as leaching and removed by plants. Soil is acidic as a result of removal of basic cations $\left(\mathrm{Ca}^{2+}, \mathrm{Mg}^{2+}\right.$ and $\left.\mathrm{K}^{+}\right)$from the soil solution mainly as a result of leaching. The application the understudied compost, co-composted biochars and biochar to infertile and acidic soil is a greater opportunity in terms of solving the current worldwide soil acidity and infertility problems in which inorganic fertilizers could not do. This is because of the understudied organic fertilizers have enough contents of $\mathrm{K}, \mathrm{Ca}$ and $\mathrm{Mg}$, for example concentration of $\mathrm{Mg}$ higher in these organic fertilizers than the lower limit of $\mathrm{Mg}$ is soil, i.e., $<15 \mathrm{mg} / \mathrm{kg}$ [53].

The concentrations of iron $(\mathrm{Fe})$, manganese $(\mathrm{Mn})$, cupper $(\mathrm{Cu})$, zinc $(\mathrm{Zn})$, lead $(\mathrm{Pb})$, and chromium (Cr) for the under investigated composts ranged from 7.22 to $14.27,3.69$ to $7.41,0.14$ to $0.22,0.96$ to 1.10, 0.11 to 0.17 , and 0.15 to $0.29 \mathrm{mg} / \mathrm{kg}$, respectively, whereas cadmium (Cd) concentration was negligible (Table 5). The low levels of heavy metals in all the under studied composts were due to lower portion of e-waste in the municipal solid waste in Jimma city. The concentrations of the heavy metals were by far lower than the results found by [56]. According to literature, the effect of biochar during composting 
is reducing the heavy metal contents in the compost pile [57]. Ho et al. [58] also found that heavy metals in the initial biosolids were converted from labile fractions into relatively immobile phases upon maturation of compost. During composting, the initial concentrations of $\mathrm{Pb}, \mathrm{Cr}, \mathrm{Fe}, \mathrm{Mn}$, and $\mathrm{Cu}$ in the organic waste mix were reduced, whereas the concentration of $\mathrm{Zn}$ in the initial organic waste mix was increased for all the compost treatments. The results also indicated that the khat-derived biochar amended compost had the greater capacity for reducing the contents of $\mathrm{Pb}, \mathrm{Cr}, \mathrm{Fe}, \mathrm{Cu}$, and $\mathrm{Mn}$ than the controlled compost. This means the sorption strength of $\mathrm{Fe}, \mathrm{Mn}$, and $\mathrm{Cu}$ on khat-derived biochar is higher than $\mathrm{Zn}$. The maximum adsorption capacities $(\mathrm{mg} / \mathrm{g})$ of metals by sesame straw biochar were in the order of $\mathrm{Pb}(102)>\mathrm{Cd}(86)>\mathrm{Cr}(65)>\mathrm{Cu}(55)>\mathrm{Zn}$ (34) in the monometal adsorption isotherm and $\mathrm{Pb}(88)>\mathrm{Cu}(40)>\mathrm{Cr}(21)>\mathrm{Zn}(7)>\mathrm{Cd}(5)$ in the multimetal adsorption isotherm [59]. In the presence of different heavy metal ions $\left(\mathrm{Pb}^{2+}, \mathrm{Cd}^{2+}, \mathrm{Cu}^{2+}, \mathrm{Zn}^{2+}\right.$, and $\left.\mathrm{Ni}^{2+}\right), \mathrm{Pb}^{2+}$ and $\mathrm{Cu}^{2+}$ showed preferential adsorption on the surface of biochar [60]. According to the study by [61], the removal percentages (\%) of heavy metals $(\mathrm{Fe}, \mathrm{Mn}, \mathrm{Cr}, \mathrm{Cu}, \mathrm{Zn}, \mathrm{Ni}$, and $\mathrm{Pb}$ ) from sludge compost by artificial zeolite significantly reduced $\mathrm{Cr}$ (43.7\%), Mn (35.8\%), and Fe (29.9\%), which are higher than Zn. However, there is lack of data on the sorption strength of Fe and Mn on the surface of compost and biochar pores. Yang et al. [62] found that the $\mathrm{Zn}$ sorption rate decreased as the compost ratio increased in amendment mixtures. So, the concentration of $\mathrm{Zn}$ decreased with decreasing the portion of organic mix from $5 \%$ to $25 \%$ khat-derived biochar amended composts. The reduction in the contents of the heavy metals in the under investigated composts was similar with the findings by [57].

Table 5. The concentrations of trace metallic elements in the initial organic waste mix and different types of co-composted khat-derived biochar. Results are expressed as mean values $\pm S D, n=3$.

\begin{tabular}{ccccccc}
\hline & \multicolumn{3}{c}{ Treatments } \\
\hline Parameters & Units & $\begin{array}{c}\text { Initial } \\
\text { Organic } \\
\text { Waste Mix }\end{array}$ & $\begin{array}{c}\text { Control } \\
\text { Compost }\end{array}$ & $\begin{array}{c}\mathbf{5 \%} \\
\text { Co-Composted } \\
\text { Biochar }\end{array}$ & $\begin{array}{c}\mathbf{1 5 \%} \text { Co-Composted } \\
\text { Biochar }\end{array}$ & $\begin{array}{c}\text { Co-Composted } \\
\text { Biochar }\end{array}$ \\
\hline $\mathrm{Fe}$ & $\mathrm{mg} / \mathrm{kg}$ & $17.03 \pm 0.04 \mathrm{a}$ & $14.27 \pm 0.02 \mathrm{~b}$ & $7.22 \pm 0.03 \mathrm{c}$ & $9.02 \pm 0.11 \mathrm{~d}$ & $12.61 \pm 0.04 \mathrm{e}$ \\
$\mathrm{Mn}$ & $\mathrm{mg} / \mathrm{kg}$ & $10.05 \pm 0.09 \mathrm{a}$ & $3.69 \pm 0.03 \mathrm{~b}$ & $6.88 \pm 0.03 \mathrm{c}$ & $7.01 \pm 0.16 \mathrm{c}$ & $7.41 \pm 0.02 \mathrm{e}$ \\
$\mathrm{Cu}$ & $\mathrm{mg} / \mathrm{kg}$ & $0.28 \pm 0.00 \mathrm{a}$ & $0.22 \pm 0.00 \mathrm{~b}$ & $0.14 \pm 0.00 \mathrm{c}$ & $0.17 \pm 0.01 \mathrm{~d}$ & $0.18 \pm 0.00 \mathrm{e}$ \\
$\mathrm{Zn}$ & $\mathrm{mg} / \mathrm{kg}$ & $0.88 \pm 0.02 \mathrm{a}$ & $0.97 \pm 0.02 \mathrm{~b}$ & $1.10 \pm 0.2 \mathrm{c}$ & $0.98 \pm 0.01 \mathrm{~b}$ & $0.96 \pm 0.00 \mathrm{~b}$ \\
$\mathrm{~Pb}$ & $\mathrm{mg} / \mathrm{kg}$ & $0.17 \pm 0.02 \mathrm{a}$ & $0.14 \pm 0.01 \mathrm{~b}$ & $0.13 \pm 0.01 \mathrm{bc}$ & $0.15 \pm 0.01 \mathrm{bd}$ & $0.11 \pm 0.00 \mathrm{e}$ \\
$\mathrm{Cd}$ & $\mathrm{mg} / \mathrm{kg}$ & - & - & - & - & - \\
$\mathrm{Cr}$ & $\mathrm{mg} / \mathrm{kg}$ & $0.29 \pm 0.02 \mathrm{a}$ & $0.28 \pm 0.01 \mathrm{a}$ & $0.22 \pm 0.02 \mathrm{c}$ & $0.21 \pm 0.02 \mathrm{c}$ & $0.15 \pm 0.01 \mathrm{e}$ \\
\hline
\end{tabular}

Generally, the organic matter in the compost is able to adsorb heavy metals and reduce their solubility resulting in immobilization [63]. This effect is enhanced by application of biochar during composting. Previous study has showed that in biochar, having small and low-volume pores, surface area availability is high for the adsorption or chemical reactions to take place [64]. The weakly alkaline media of the biochar also reduce the solubility and facilitate immobilization and accumulation of these metals. So, the decrease in heavy metal content has been associated to accumulation and immobilization of mobile metal fractions in the pores of biochar and organic matters of compost pile.

There is a requirement for limits on the contents of heavy metals to ensure that compost is safe to use for agriculture. High contents of heavy metals in municipal solid waste compost affect soil microbes. Heavy metals are plant nutrients at trace level but, they are toxic when they are accumulated. All the heavy metals are within the quality control limit of the fertilizer order by [65].

Although essential heavy metals are required with trace level by plants, recently studies showed that the application of trace essential elements such as zinc-based fertilizer increases the productivity of crops. So, to incorporate compost for the correction of trace metal deficiency in soils, it can be concluded that the compost under investigation can be valuably applied in $\mathrm{Zn}$ deficient soils, as the concentrations of other heavy metals $(\mathrm{Pb}, \mathrm{Cr}, \mathrm{Fe}, \mathrm{Mn}$, and $\mathrm{Cu})$ were found to be lower than the permissible levels. 


\section{Conclusions and Recommendation}

The initial organic waste mix nutrient increased significantly due to the addition of khat-derived biochar during composting than without biochar. This is due to khat derived biochar optimized the mineralization and adsorbs nutrients from the organic waste mix. In addition high preserves of nutrients in khat-derived biochar also increased important nutrient in the co-composted biochar piles. In our study we concluded that the $5 \%$ and $15 \%(w / w)$ khat derived biochar rates were the optimum rates which increased significantly the total $\mathrm{N}$, total organic carbon, $\mathrm{P}, \mathrm{K}, \mathrm{Ca}, \mathrm{Mg}, \mathrm{CEC}, \mathrm{pH}$ and $\mathrm{Zn}$ compared to the control compost (no biochar). So, it is recommended to apply khat-derived biochar with rates of $5-15 \%$ during composting of organic fractions of municipal solid waste. The findings from this experimental study showed that co-composting of khat-derived biochar and organic fractions of municipal solid waste could be the suitable and sustainable practice to improve waste management in municipalities of Ethiopia through production of enough quality biofertilizer. Although, khat derived biochar and khat-derived co-composted biochar from municipal solid waste sources preserve enough contents of plant nutrients, field experiment test and health risk assessment are essential before for large scale applications.

Author Contributions: Conceptualization, Z.A.T., K.P., and M.L.; methodology, Z.A.T., A.B., and A.N.; investigation, Z.A.T., A.B., and A.N.; resources, Z.A.T., A.B., A.N., K.P., and M.L.; data curation, Z.A.T., A.B., A.N., K.P., and M.L.; writing-original draft preparation, Z.A.T., A.B., and A.N.; writing—review and editing, K.P. and M.L.; project administration, M.L.; funding acquisition, K.P. All authors have read and agreed to the published version of the manuscript.

Funding: Publication was funded by the research subsidy allocated for 2020 (08/030/BK_20/0079).

Acknowledgments: The authors wish to thank the Jimma University and Debremarkos University for their financial and logistic support. We also thank the staff of Debremarkos Soil Laboratory and Amhara Design and Supervision Work Enterprise Laboratory Services for providing support to conduct the laboratory determination.

Conflicts of Interest: The authors declare no conflict of interest.

\section{References}

1. Menikpura, S.N.M.; Sang-Arun, J.; Bengtsson, M. Integrated Solid Waste Management: An approach for enhancing climate co-benefits through resource recovery. J. Clean. Prod. 2013, 58, 34-42. [CrossRef]

2. Jouhara, H.; Czajczyńska, D.; Ghazal, H.; Krzyżyńska, R.; Anguilano, L.; Reynolds, A.J.; Spencer, N. Municipal waste management systems for domestic use. Energy 2017, 139, 485-506. [CrossRef]

3. Getahun, T.; Mengistie, E.; Haddis, A.; Wasie, F.; Alemayehu, E.; Dadi, D.; Gerven, T.V.; Bruggen, B.V.D. Municipal solid waste generation in growing urban areas in Africa: Current practices and relation to socioeconomic factors in Jimma, Ethiopia. Env. Monit. Assess 2012, 184, 6337-6345. [CrossRef] [PubMed]

4. Ruggieri, L.; Cadena, E.; Martínez-Blanco, J.; Gasol, C.M.; Rieradevall, J.; Gabarrell, X.; Gea, T.; Sort, X.; Sánchez, A. Recovery of organic wastes in the Spanish wine industry. Technical, economic and environmental analyses of the composting process. J. Clean. Prod. 2009, 17, 830-838. [CrossRef]

5. Oviedo-Ocana, E.R.; Torres-Lozada, P.; Marmolejo-Rebellon, L.F.; Hoyos, L.V.; Gonzales, S.; Barrena, R.; Komilis, D.; Sanchez, A. Stability and maturity of biowaste composts derived by small municipalities: Correlation among physical, chemical and biological indices. Waste Manag. 2015, 44, 63-71. [CrossRef]

6. Lohri, C.R.; Diener, S.; Zabaleta, I.; Mertenat, A.; Zurbrügg, C. Treatment technologies for urban solid biowaste to create value products: A review with focus on low- and middle-income settings. Rev. Environ. Sci. Bio/Technol. 2017, 16, 81-130. [CrossRef]

7. Jara-Samaniego, J.; Pérez-Murcia, M.D.; Bustamante, M.A.; Pérez-Espinosa, A.; Paredes, C.; López, M.; López-Lluch, D.B.; Gavilanes-Terán, I.; Moral, R. Composting as sustainable strategy for municipal solid waste management in the Chimborazo Region, Ecuador: Suitability of the obtained composts for seedling production. J. Clean. Prod. 2017, 141, 1349-1358. [CrossRef]

8. Geng, Y.; Cao, G.; Wang, L.; Wang, S. Effects of equal chemical fertilizer substitutions with organic manure on yield, dry matter, and nitrogen uptake of spring maize and soil nitrogen distribution. PLOS ONE 2019, 14, e0219512. [CrossRef] 
9. Pikoń, K.; Bogacka, M.; Czarnowska, L.; Stanek, W.; Nadziakiewicz, J. Environmental evaluation methodology of fossil fuels. In Proceedings of the 14th International Multidisciplinary Scientific GeoConference SGEM, GeoConference on Energy and Clean Technologies 2014, Albena, Bulgaria, 17-26 June 2014; SGEM: Sofia, Bulgary, 2014; Volume 1, pp. 205-212.

10. Czop, M.; Kajda-Szcześniak, M.; Bogacka, M. Analysis focus on energetic and environmental impact of waste biomass use. In Proceedings of the 16th International Multidisciplinary Scientific GeoConference, GeoConference on Nuclear Technologies, Renewable Energy Sources and Clean Technologies 2016, Albena, Bulgaria, 30 June-6 July 2016; Book 4, Energy and Clean Technologies. SGEM: Sofia, Bulgary, 2016; Volume 1, pp. 99-106.

11. Schulz, H.; Dunst, G.; Glaser, B. Positive effects of composted biochar on plant growth and soil fertility. Agron. Sustain. Dev. 2013, 33, 817-827. [CrossRef]

12. Ravindran, B.; Nguyen, D.D.; Chaudhary, D.K.; Chang, S.W.; Kim, J.; Lee, S.R.; Shin, J.; Jeon, B.H.; Chung, S.; Lee, J. Influence of biochar on physico-chemical and microbial community during swine manure composting process. J. Environ. Manag. 2019, 232, 592-599. [CrossRef] [PubMed]

13. Dias, B.O.; Silva, C.A.; Higashikawa, F.S.; Roig, A.; Sanchez-Monedero, M.A. Use of biochar as bulking agent for the composting of poultry manure: Effect on organic matter degradation and humification. Bioresour. Technol. 2010, 101, 1239-1246. [CrossRef] [PubMed]

14. Vandecasteele, B.; Sinicco, T.; D’Hose, T.; Vanden Nest, T.; Mondini, C. Biochar amendment before or after composting affects compost quality and $\mathrm{N}$ losses, but not P plant uptake. J. Environ. Manag. 2016, 168, 200-209. [CrossRef] [PubMed]

15. Malińska, K.; Zabochnicka-Świątek, M.; Dach, J. Effects of biochar amendment on ammonia emission during composting of sewage sludge. Ecol. Eng. 2014, 71, 474-478. [CrossRef]

16. Jindo, K.; Suto, K.; Matsumoto, K.; Garcia, C.; Sonoki, T.; Sanchez-Monedero, M.A. Chemical and biochemical characterisation of biochar-blended composts prepared from poultry manure. Bioresour. Technol. 2012, 110, 396-404. [CrossRef]

17. Wu, H.; Lai, C.; Zeng, G.; Liang, J.; Chen, J.; Xu, J.; Dai, J.; Li, X.; Liu, J.; Chen, M.; et al. The interactions of composting and biochar and their implications for soil amendment and pollution remediation: A review. Crit. Rev. Biotechnol. 2017, 37, 754-764. [CrossRef]

18. Xiao, R.; Awasthi, M.K.; Li, R.; Park, J.; Pensky, S.M.; Wanga, Q.; Wang, J.J.; Zhang, Z. Recent developments in biochar utilization as an additive in organic solid waste composting: A review. Bioresour. Technol. 2017, 246, 203-213. [CrossRef]

19. Jindo, K.; Mizumoto, H.; Sawada, Y.; Sanchez-Monedero, M.A.; Sonoki, T. Physical and chemical characterization of biochars derived from different agricultural residues. Biogeosciences 2014, 11, 6613-6621. [CrossRef]

20. Qian, K.; Kumar, A.; Zhang, H.; Bellmer, D.; Huhnke, R. Recent advances in utilization of biochar. Renew. Sustain. Energy Rev. 2015, 42, 1055-1064. [CrossRef]

21. Mukherjee, A.; Lal, R.; Zimmerman, A.R. Effects of biochar and other amendments on the physical properties and greenhouse gas emissions of an artificially degraded soil. Sci. Total Environ. 2014, 487, 26-36. [CrossRef]

22. Fern, S.G.L.; Wilson, O.B. Influence of biochar and compost on soil properties and tree growth in a tropical urban environment. Int. J. Environ. Sci. Technol. 2015, 12, 1303-1310.

23. Hall, D.J.M.; Bell, R.W. Biochar and Compost Increase Crop Yields but the Effect is Short Term on Sandplain Soils of Western Australia. Pedosphere 2015, 25, 720-728. [CrossRef]

24. Wu, W.; Yang, M.; Feng, Q.; McGrouther, K.; Wang, H.; Lu, H.; Chen, Y. Chemical characterization of rice straw-derived biochar for soil amendment. Biomass Bioenergy 2012, 47, 268-276. [CrossRef]

25. Zhang, J.; Lü, F.; Luo, C.; Shao, L.; He, P. Humification characterization of biochar and its potential as a composting amendment. J. Environ. Sci. 2014, 26, 390-397. [CrossRef]

26. Chowdhury, M.A.; de Neergaard, A.; Jensen, L.S. Potential of aeration flow rate and bio-char addition to reduce greenhouse gas and ammonia emissions during manure composting. Chemosphere 2014, 97, 16-25. [CrossRef] [PubMed]

27. Antonangelo, A.; Sun, X.; Zhang, H. The roles of co-composted biochar (COMBI) in improving soil quality, crop productivity, and toxic metal amelioration. J. Environ. Manag. 2020, 277. [CrossRef]

28. Ronsse, F.; van Hecke, S.; Dickinson, D.; Prins, W. Production and characterization of slow pyrolysis biochar: Influence of feedstock type and pyrolysis conditions. GCB Bioenergy 2013, 5, 104-115. [CrossRef] 
29. Batjes, N.H. Total carbon and nitrogen in the soils of the world. Eur. J. Soil Sci. 1996, 47, 151-163. [CrossRef]

30. Qian, X.; Shen, G.; Wang, Z.; Guo, C.; Liu, Y.; Lei, Z.; Zhang, Z. Co-composting of livestock manure with rice straw: Characterization and establishment of maturity evaluation system. Waste Manag. 2014, 34, 530-535. [CrossRef]

31. Jackson, M.L. Soil Chemical Analysis; Prentice Hall: Englewood Cliffs, NJ, USA, 1958. [CrossRef]

32. Anderson, J.M.; Ingram, J.S.L. Tropical Soil Biology and Fertility-A Handbook of Methods; CAB International: Wallingford, UK, 1993.

33. Sumner, M.E.; Miller, W.P. Cation Exchange Capacity and Exchange Coefficients. In Methods of Soil Analysis Part 3: Chemical Methods, SSSA Book Series 5; Sparks, D.L., Ed.; Soil Science Society of America: Madison, WI, USA, 1996; pp. 1201-1230.

34. Steel, G.D.; Torrie, J. Process and Procedures of Statistics. A Biometrical Approach, 2nd ed.; McGraw Hill Book: New York, NY, USA, 1979.

35. Lasaridi, K.; Protopapa, I.; Kotsou, M.; Pilidis, G.; Manios, T.; Kyriacou, A. Quality assessment of composts in the Greek market: The need for standards and quality assurance. J. Environ. Manag. 2006, 80, 58-65. [CrossRef]

36. Piash, M.I.; Hossain, M.F.; Parveen, Z. Physico-chemical properties and nutrient content of some slow pyrolysis biochars produced from different feedstocks. Bangladesh J. Sci. Res. 2016, 29, 111-122. [CrossRef]

37. Khater, E.-S.G. Some Physical and Chemical Properties of Compost. Int. J. Waste Resour. 2015, 5, 1-5. [CrossRef]

38. Zhang, J.; Chen, G.; Sun, H.; Zhou, S.; Zou, G. Straw biochar hastens organic matter degradation and produces nutrient-rich compost. Bioresour. Technol. 2016, 200, 876-883. [CrossRef] [PubMed]

39. Rashad, F.M.; Saleh, W.D.; Moselhy, M.A. Bioresource Technology Bioconversion of rice straw and certain agro-industrial wastes to amendments for organic farming systems: 1. Composting, quality, stability and maturity indices. Bioresour. Technol. 2010, 101, 5952-5960. [CrossRef] [PubMed]

40. Cesaroa, A.; Belgiornoa, V.; Guidaba, M. Compost from organic solid waste: Quality assessment and European regulations for its sustainable use. Resour. Conserv. Recycl. 2015, 94, 72-79. [CrossRef]

41. Harada, Y.; Inoko, A. The measurement of the cation-exchange capacity of composts for the estimation of the degree of maturity. Soil Sci. Plant Nutr. 2012, 26, 127-134. [CrossRef]

42. Petric, I.; Šestan, A.; Šestan, I. Influence of initial moisture content on the composting of poultry manure with wheat straw. Biosyst. Eng. 2009, 104, 125-134. [CrossRef]

43. Khan, N.; Clark, I.; Sánchez-Monedero, M.A.; Shea, S.; Meier, S.; Bolan, N. Maturity indices in co-composting of chicken manure and sawdust with biochar. Bioresour. Technol. 2014, 168, 245-251. [CrossRef]

44. Awasthi, M.K.; Pandey, A.K.; Bundela, P.S.; Khan, J. Co-composting of organic fraction of municipal solid waste mixed with different bulking waste: Characterization of physicochemical parameters and microbial enzymatic dynamic. Bioresour. Technol. 2015, 182, 200-207. [CrossRef]

45. Schuchardt, F.; Wang, Y.Q. Effect of C/N ratio on the composting of vineyard pruning residues. Agric. For. Res. 2010, 3, 131-138.

46. Jindo, K.; Sánchez-Monedero, M.A.; Matsumoto, K.; Sonoki, T. The Efficiency of a Low Dose of Biochar in Enhancing the Aromaticity of Humic-Like Substance Extracted from Poultry Manure Compost. Agronomy 2019, 9, 248. [CrossRef]

47. Guo, R.; Li, G.; Jiang, T.; Schuchardt, F.; Chen, T.; Zhao, Y.; Shen, Y. Effect of aeration rate, C/N ratio and moisture content on the stability and maturity of compost. Bioresour. Technol. 2012,112, 171-178. [CrossRef] [PubMed]

48. Pathak, A.K.; Singh, M.M.; Kumar, V. Composting of municipal solid waste: A sustainable waste management technique in Indian cities-A Review. Int. J. Curr. Res. 2011, 3, 339-346.

49. Wilson, G.B. A guide providing a suitable environment and source of nutrients to optimize the composting process. Biocycle 1989, 29, 82-86.

50. Lopez-Cano, I.; Roig, A.; Cayuela, M.L.; Alburquerque, J.A.; Sanchez-Monedero, M.A. Biochar improves $\mathrm{N}$ cycling during composting of olive mill wastes and sheep manure. Waste Manag. 2016, 49, 553-559. [CrossRef]

51. Agyarko-Mintah, E.; Cowie, A.; Van Zwieten, L.; Singh, B.P.; Smillie, R.; Harden, S.; Fornasier, F. Biochar lowers ammonia emission and improves nitrogen retention in poultry litter composting. Waste Manag. 2017, 61, 129-137. [CrossRef] 
52. Lehmann, J.; Pereira da Silva, J., Jr.; Steiner, C.; Nehls, T.; Zech, W.; Glaser, B. Nutrient availability and leaching in an archaeological Anthrosol and a Ferralsol of the Central Amazon basin: Fertilizer, manure and charcoal amendments. Plant Soil 2003, 249, 343-357. [CrossRef]

53. Kidder, G.; Chambliss, C.G.; Mylavarapu, R. UF/IFAS Standardized Fertilization Recommendations for Agronomic Crops. SL129; IFAS: Gainesville, FL, USA, 2002; p. 9.

54. Pandit, N.R.; Schmidt, H.P.; Mulder, J.; Hale, S.E.; Husson, O.; Cornelissen, G. Nutrient effect of various composting methods with and without biochar on soil fertility and maize growth. Arch. Agron. Soil Sci. 2020, 66, 250-265. [CrossRef]

55. Meller, E.; Niedźwiecki, E.; Rogalska, P.; Jarnuszewski, G.; Wilczyński, D. Fertiliser Value and Trace Element Content of Composts Produced from Different Wastes. J. Ecol. Eng. 2015, 16, 154-160. [CrossRef]

56. Hagemann, N.; Subdiaga, E.; Orsetti, S.; Rosa, J.M.; Knicker, H.; Schmidt, H.-P.; Kappler, A.; Behrens, S. Effect of biochar amendment on compost organic matter composition following aerobic composting of manure. Sci. Total Environ. 2018, 613-614, 20-29.

57. Zeng, G.; Wu, H.; Liang, J.; Guo, S.; Huang, L.; Xu, P.; Liu, Y.; Yuan, Y.; Heab, X.; Heab, Y. Efficiency of biochar and compost (or composting) combined amendments for reducing $\mathrm{Cd}, \mathrm{Cu}, \mathrm{Zn}$ and $\mathrm{Pb}$ bioavailability, mobility and ecological risk in wetland soil. R. Socity Chem. 2015, 5, 34541-34548. [CrossRef]

58. Ho, C.P.; Yuan, S.T.; Jien, S.H.; Hseu, Z.Y. Elucidating the process of co-composting of biosolids and spent activated clay. Bioresour. Technol. 2010, 101, 8280-8286. [CrossRef] [PubMed]

59. Park, J.H.; Ok, Y.S.; Kim, S.H.; Cho, J.S.; Heo, J.S.; Delaune, R.D.; Seo, D.C. Competitive adsorption of heavy metals onto sesame straw biochar in aqueous solutions. Chemosphere 2016, 142, 77-83. [CrossRef] [PubMed]

60. Ding, Z.; Hu, X.; Wan, Y.; Wang, S.; Gao, B. Removal of lead, copper, cadmium, zinc, and nickel from aqueous solutions by alkali-modified biochar: Batch and column tests. J. Ind. Eng. Chem. 2016, 33, 239-245. [CrossRef]

61. Ozdemir, S.; Turp, S.M.; Oz, N. Simultaneous dry-sorption of heavy metals by porous adsorbents during sludge composting. Environ. Eng. Res. 2019, 25, 258-265. [CrossRef]

62. Yang, Z.; Liang, J.; Tang, L.; Zeng, G.; Yu, M.; Li, X.; Li, X.; Qian, Y.; Wu, H.; Luo, Y.; et al. Sorption-desorption behaviors of heavy metals by biochar-compost amendment with different ratios in contaminated wetland soil. J. Soils Sediments 2017, 18, 1530-1539. [CrossRef]

63. Smith, S.R. A critical review of the bioavailability and impacts of heavy metals in municipal solid waste composts compared to sewage sludge. Environ. Int. 2009, 35, 142-156. [CrossRef]

64. Gunarathne, V.; Ashiq, A.; Ramanayaka, S.; Wijekoon, P.; Vithanage, M. Biochar from municipal solid waste for resource recovery and pollution remediation. Environ. Chem. Lett. 2019, 17, 1225-1235. [CrossRef]

65. FAO. The State of Food and Agriculture; FAO: Rome, Italy, 1985.

Publisher's Note: MDPI stays neutral with regard to jurisdictional claims in published maps and institutional affiliations.

(C) 2020 by the authors. Licensee MDPI, Basel, Switzerland. This article is an open access article distributed under the terms and conditions of the Creative Commons Attribution (CC BY) license (http://creativecommons.org/licenses/by/4.0/). 